\title{
Testemunhos da violência na obra do Mapa Teatro, Colômbia
}

\author{
To witness violence in the work of Mapa Teatro, \\ Colômbia \\ Testigos de la violencia en la obra de Mapa \\ Teatro, Colombia
}

Clara Barzaghi Laurentiis Mestre em psicologia clínica (PUCSP) e doutoranda em arquitetura e urbanismo (UNICAMP). Pesquisa urbanismo, arte e violência na América Latina. Instituição: Faculdade de Engenharia Civil, Arquitetura e Urbanismo, Unicamp

E-mail: clarabarzaghi2@gmail.com ORCID: https://orcid.org/0000-0002-5903-4489

Peter Pal Pelbart Professor Titular nos Departamentos de Filosofia e Psicologia Clínica da Pontifícia Universidade Católica de São Paulo Instituição: Pontifícia Universidade Católica de São Paulo (PUCSP)

E-mail: pppelbart@gmail.com ORCID: https://orcid.org/0000-0003-1880-0113

RESUMO:

O laboratório de artistas Mapa Teatro, ao optar por fazer uma Anatomia da violência na Colômbia, abandona a univocidade de documentos históricos para combiná-los com verdades inventadas ou mentiras sinceras e criar etnoficções, suscitando perspectivas que não correspondem à narrativa dominante da História. Apresento uma aproximação em relação a algumas obras do grupo para criar perspectivas críticas em relação à grade de codificação e descodificação do que se costuma entender como violência e suas implicações subjetivas bem como suas manifestações macropolíticas.

Palavras-chave: Arquivo vivo. Testemunha. Violência.

LAURENTIIS, Clara Barzaghi; PELBART, Peter Pal. Testemunhos da violência na obra do Mapa Teatro, Colômbia.

PÓS:Revista do Programa de Pós-graduação em Artes da EBA/UFMG. v.10, n.19: mai.2020

Disponível em < $\underline{\text { https://eba.ufmg.br/revistapos }}>$ 


\section{ABSTRACT:}

When Mapa Teatro laboratory of artists chooses to develop an Anatomy of violence in Colombia, the group abandons the univocality of historical documents to combine them with fake truths or sincere lies, in order to create ethnofictions which raise perspectives that do not correspond to History's dominant narrative. I present here an approach towards some of the group's artwork, aiming to create critical perspectives relating to coding e decoding structures of what is commonly understood as violence and its subjective implications, as well as its macropolitical manifestations.

Keywords: Living Archive. Witness. Violence.

\section{RESUMEN:}

Cuando el Laboratorio de artistas de Mapa Teatro desarrolla una Anatomía de la Violencia en Colombia, el grupo abandona la univocidad de los documentos históricos para los combinar con falsas verdades o mentiras sinceras, para crear etnoficciones que levantan perspectivas que no corresponden a la narrativa dominante de la Historia. Presento aqui una aproximación en dirección al trabajo del grupo, intentando crear perspectivas críticas en relación a la grade de codificación y decodificación de lo que se suele comprender como violencia y sus implicaciones subjetivas, tal como sus manifestaciones macropolíticas.

Palabras clave: Archivo vivo. Testigo. Violencia

Artigo recebido em: 07/09/2019

Artigo aprovado em: 28/02/2020

LAURENTIIS, Clara Barzaghi; PELBART, Peter Pal. Testemunhos da violência na obra do Mapa Teatro, Colômbia.

PÓS:Revista do Programa de Pós-graduação em Artes da EBA/UFMG. v.10, n.19: mai.2020

Disponível em < $\underline{\text { https://eba.ufmg.br/revistapos }}>$

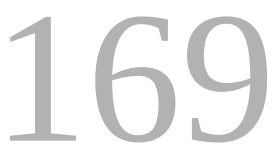


Não parece haver conclusões definitivas ou síntese quando se trata do laboratório de artistas Mapa Teatro. Ora, isso não é nenhuma novidade naquilo que se costuma chamar arte contemporânea, mas o grupo colombiano chama a atenção porque sua produção frequentemente recai sobre o curso da História, especificamente da história colombiana, o que abre a possibilidade para que alguns de seus processos criativos se desdobrem indefinidamente.

Os irmãos Rolf e Heidi Abderhalden, fundadores e diretores do Mapa Teatro, visitaram, em 2001, o bairro Santa Inés/El Cartucho pela primeira vez durante o processo de desalojamento forçado dos moradores cujas casas seriam postas abaixo, abrindo espaço para o Parque Tercer Milenio. Localizado na região central de Bogotá, o bairro assombrava o imaginário da cidade como reduto de delinquentes e território do medo.

Entre 2001 e 2005, o Mapa Teatro articulou uma série de seus trabalhos ao processo de demolição de El Cartucho a partir de uma convocação do então prefeito Antanas Mockus, que "recém eleito prefeito de Bogotá e não podendo reverter a desaparição do bairro (...) quis que ao menos restasse alguma marca do que, durante décadas, havia sido a vida naquelas ruas" (SÁNCHEZ, 2016, p. 310).

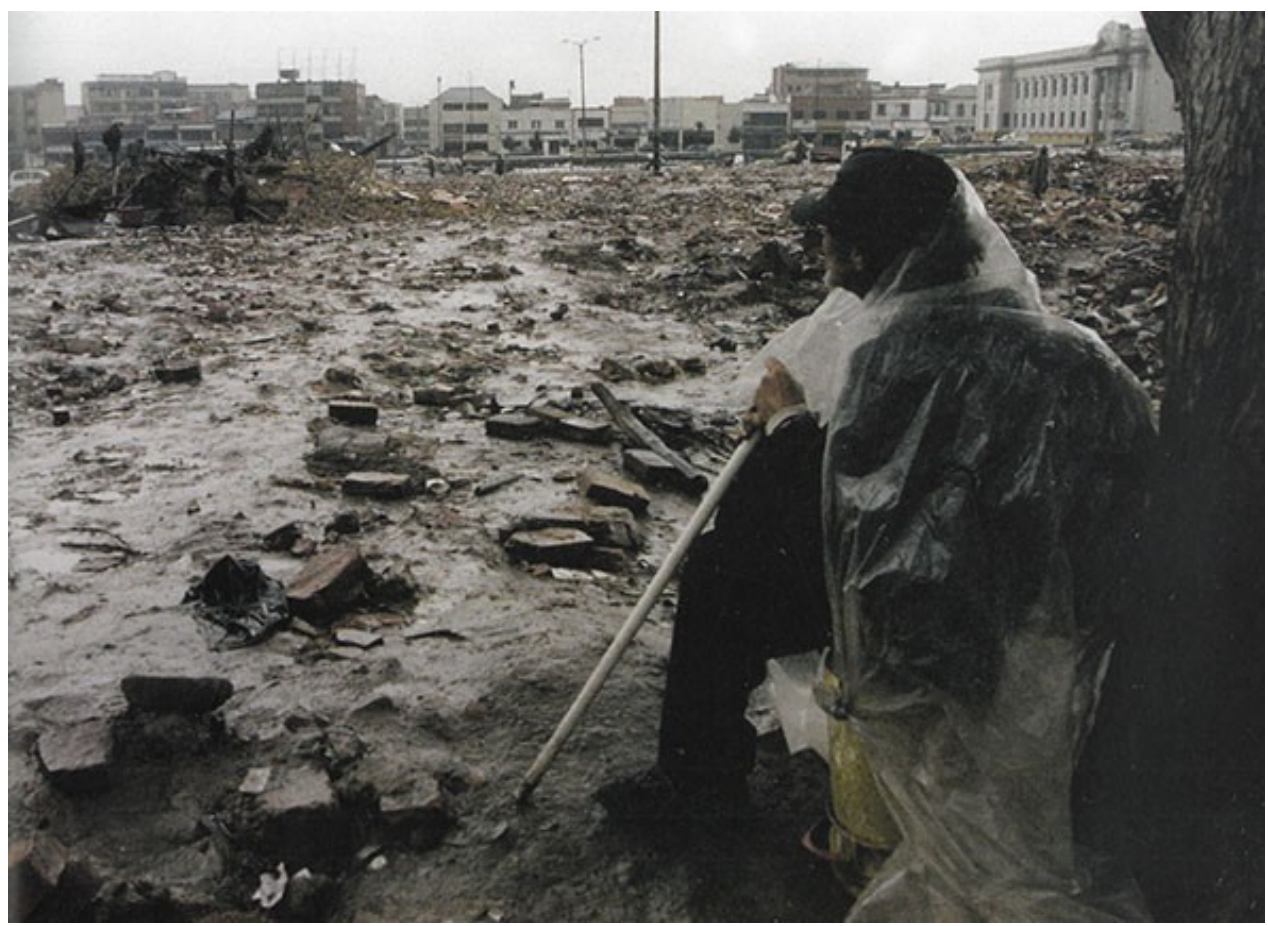

Fig. 1 - Registro realizado pela equipe do Mapa Teatro durante o projeto C'úndua. Bogotá, Colômbia.

LAURENTIIS, Clara Barzaghi; PELBART, Peter Pal. Testemunhos da violência na obra do Mapa Teatro, Colômbia.

PÓS:Revista do Programa de Pós-graduação em Artes da EBA/UFMG. v.10, n.19: mai.2020 Disponível em < https://eba.ufmg.br/revistapos $>$

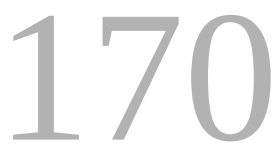


Para deixar essa marca (huella), o Mapa Teatro desenvolveu, ao lado de moradores dos bairros e outros profissionais, os projetos C'úndua (2001), Prometeo I e II atos (2001, 2002), Re-corridos (2003) e La Limpieza de los establos de Augías (2004). Ao longo de quatro anos, o grupo instaurou um laboratório do imaginário social, noção proposta por Heiner Müller, emprestada pelo dramaturgo do filósofo Wolfgang Heise (1925-1987). Durante os dois primeiros anos de projeto, esse laboratório tomou como ponto de partida o texto die Befreiung des Prometheus, de Heiner Müller. A versão de Müller do mito de Prometeu foi a matéria prima com a qual os antigos moradores de El Cartucho trabalharam para criar suas próprias versões do mito. A partir de suas leituras singulares sobre um Prometeu que teme mais a liberdade do que a eternidade acorrentado, fizeram etnoficções, narrações nas quais o real e o falsificado estão constantemente em fricção.

Vale notar que a etnoficção como procedimento é uma característica contundente do trabalho do Mapa Teatro que encontrou, em Jean Rouch (1917-2004), a referência que buscava ao tentar se distanciar de certos formalismos cênicos. Além disso, ao optar pela etnoficção, o Mapa Teatro se distancia da lógica dialética do Teatro Documentário no qual a História é o herói principal. Rouch, antropólogo e cineasta, cunha o termo para se referir a seus filmes antropológicos nos quais as imagens "torna[m]-se pensamento, capaz[es] de compreender o mecanismo do pensamento, ao mesmo tempo em que a câmera assume diversas funções que equivalem verdadeiramente a funções proposicionais" (DELEUZE, 2008, p. 73).

O antropólogo-cineasta inaugura um modo de registro que extrapola o caráter etnográfico, criando composições nas quais a realidade e o ficcional não se distinguem mais. Ao misturar improvisos frente à câmera com o que chamou de cine-transe, Rouch dissolve a separação entre sujeito/ objeto e cria imagens que são também uma reviravolta no pensamento, produzindo uma ruptura com as tradicionais dicotomias da antropologia. É o espectro de pensamento apresentado por Rouch que interessa ao Mapa Teatro, pois apresenta a possibilidade de deslocamento em relação à univocidade da Verdade e ao ponto de vista único da História. Em suas etnoficções, o grupo colombiano encontra seus próprios procedimentos para criar uma linguagem centrada nas ideias de rede e multiplicidade. Assim, seus trabalhos combinam memórias com registros históricos, textos de autores como Müller ou Beckett com relatos pessoais, fabulando narrações que admitem a existência de múltiplos pontos de vista.

LAURENTIIS, Clara Barzaghi; PELBART, Peter Pal. Testemunhos da violência na obra do Mapa Teatro, Colômbia.

PÓS:Revista do Programa de Pós-graduação em Artes da EBA/UFMG. v.10, n.19: mai.2020 Disponível em < $\underline{\text { https://eba.ufmg.br/revistapos }}>$

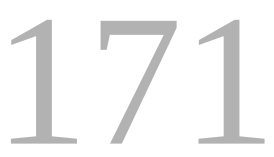


Em dezembro de 2002, foi apresentado Prometeo II, ato no bairro demolido, iluminado por velas que traçavam seus antigos caminhos. Por uma noite, a memória do bairro foi o que permitiu reconstruí-lo com objetos dos antigos moradores. Esses atuaram suas versões de Prometeu, enquanto relatos sobre suas vidas após o desalojamento forçado eram projetados em um telão. Por fim, ao som de um bolero, os moradores dançaram sobre os escombros de El Cartucho, convertendo as ruínas em um território de permanência. E o povo deslocado se torna um povo que volta e, por um tempo imensurável, permanece. A partir da construção e reconstrução de imagens e testemunhos, surgiu um sujeito coletivo, que trouxe relatos múltiplos para o espaço narrativo da cidade e desenvolveu ações que transitaram entre o real e o simbólico (ABDERHALDEN, 2014).

A marca pela qual clamava o prefeito não foi buscada pelos artistas em termos de objeto de arte; os Abderhalden optaram por promover agenciamentos estéticos, processos nos quais a criação de imagens pode produzir subjetividade (SÁNCHEZ, 2007, p. 268). Durante o processo, os moradores, e também os artistas, tornaram-se testemunhas do desaparecimento do bairro. As etnoficções criadas pelos moradores foram, ao mesmo tempo, uma forma de responder poeticamente ao desaparecimento concreto do território que ocupavam, e de reivindicar a existência de El Cartucho para além de seus limites físicos. Na ação seguinte, Re-corridos (2003), o Mapa Teatro levou a memória do bairro para sua sede, um casarão no centro de Bogotá. As singularidades das cartografias tecidas ao longo do laboratório do imaginário social se materializaram em objetos, sons, vídeos e imagens que transformaram o casarão em muitas das casas do bairro destruído.

As experiências do corpo coletivo que se formaram foram colocadas em cena em Testigo de las ruínas (2005), apresentação que retomava insistentemente o processo de desaparecimento do bairro, articulando imagens de antes, durante e depois. Cinco grandes telas recebem as imagens do bairro que se tornou canteiro de obras. Participantes do grupo movimentam essas telas pelo palco e, em meio às imagens de bolas de demolição, tapumes, vestígios de casas, montes de entulhos, escutam-se os testemunhos dos desalojados de Santa Inés/El Cartucho.

Há uma mulher em cena durante todo o tempo da apresentação. Trata-se de Juana María Ramírez, última pessoa a ser desalojada do bairro, que faz, na performance aquilo que costumava fazer em seu dia a dia: arepas, comida típica colombiana.

LAURENTIIS, Clara Barzaghi; PELBART, Peter Pal. Testemunhos da violência na obra do Mapa Teatro, Colômbia.

PÓS:Revista do Programa de Pós-graduação em Artes da EBA/UFMG. v.10, n.19: mai.2020 Disponível em < $\underline{\text { https://eba.ufmg.br/revistapos }>}$

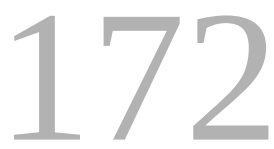




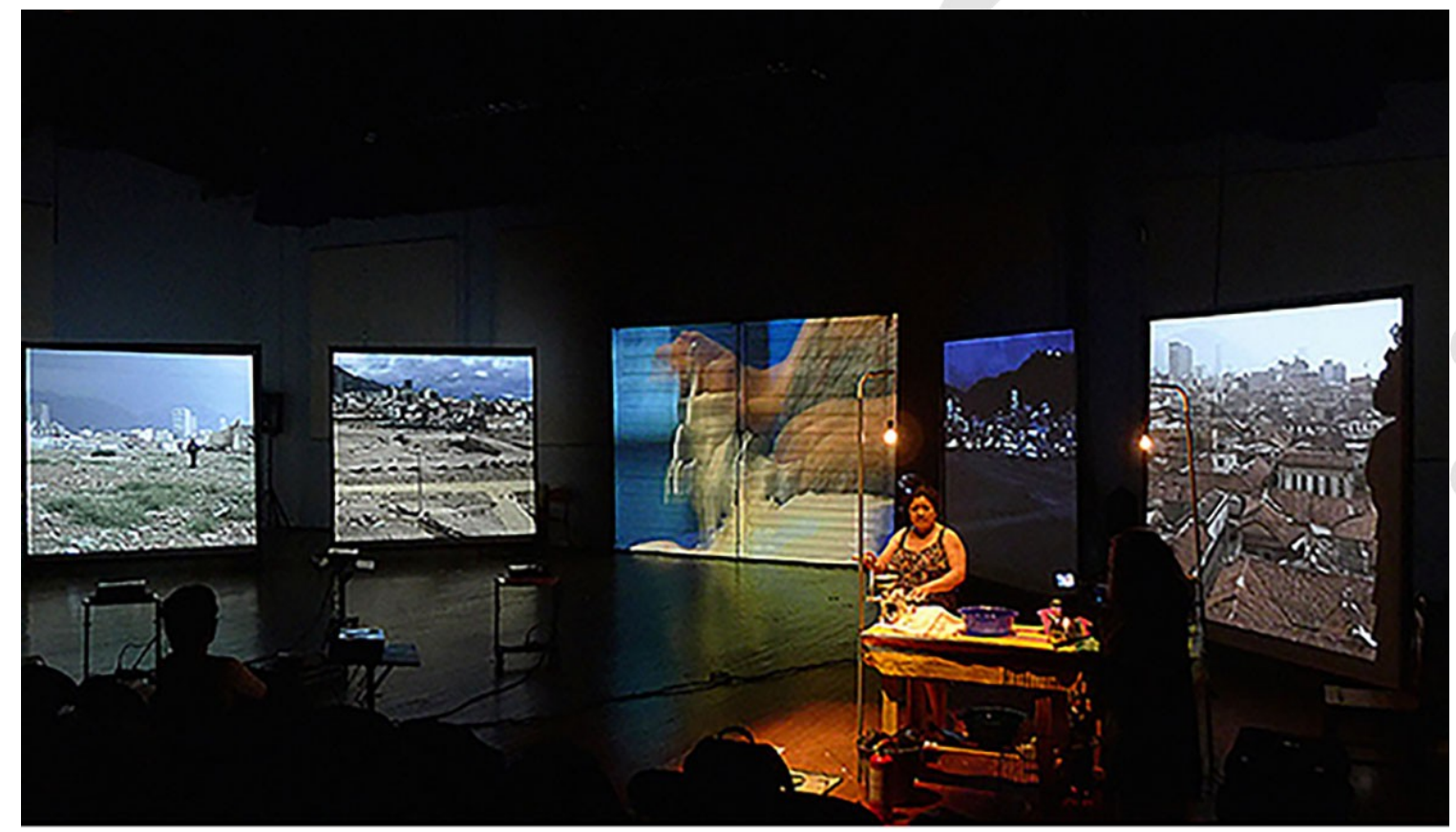

Fig. 2 - Mapa Teatro, Testigo de las Ruínas, peça de teatro, 2005. Bogotá, Colômbia.

As imagens projetadas se alternam entre o canteiro de obras, registros das entrevistas realizadas com antigos moradores, cenas de Prometeo Il ato, fotografias do Parque Tercer Milenio e um vídeo do próprio presente da cena que se constrói conforme Juana manuseia sua máquina, fazendo suas arepas. Essa relação entre o que acontece em cena e o que se passa no vídeo permite um entrelaçamento entre passado, presente e futuro, entre feitos e ficções. A presença de Juana atualiza os testemunhos de seus vizinhos cujas memórias e relatos remetem a quase 12 mil pessoas que chegaram a viver em El Cartucho.

Ela não está ali como imagem do passado, mas como memória viva de territórios destruídos. Vale notar que a noção de território, aqui, se diferencia da noção de espaço, uma vez que este se relaciona com a funcionalidade enquanto aquele está vinculado a modos de subjetivação individuais e coletivos. Na definição de Guattari, "o espaço funciona como uma referência extrínseca em relação aos objetos que ele contém. Ao passo que o território funciona em uma relação intrínseca com a subjetividade que o delimita" (GUATTARI, 1985, p. 110).

LAURENTIIS, Clara Barzaghi; PELBART, Peter Pal. Testemunhos da violência na obra do Mapa Teatro, Colômbia.

PÓS:Revista do Programa de Pós-graduação em Artes da EBA/UFMG. v.10, n.19: mai.2020 Disponível em < $\underline{\text { https://eba.ufmg.br/revistapos }}>$

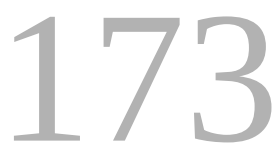


As duas noções não se opõem, mas operam juntas. A demolição de um espaço, por exemplo, de um bairro, de suas ruas, de suas casas, de seus bares e de seus becos pode mutilar territórios existenciais.

Testigo de las ruínas, assim como os outros trabalhos do grupo relacionados à construção do Parque Tercer Milênio, tem como principal matéria prima os relatos e recordações de habitantes do bairro desapropriado em nome de melhorias urbanas. Mas, aqui, nas cinco grandes telas que se movimentam pelo palco, vemos a tentativa dos Abderhalden darem seu próprio testemunho do que vivenciaram ao longo da experiência com o coletivo que se formou. É, pois, "o reconhecimento de que a memória do processo não é só dos que habitaram o bairro e foram desapossados, mas também dos que testemunharam e ficaram marcados fisicamente pela experiência de um tempo compartilhado" (SÁNCHEZ, 2016, p. 311).

O que o Mapa Teatro apresenta é um arquivo construído ao longo desse tempo compartilhado. Esses registros são documentos que evidenciam como, em função do discurso de renovação urbana e segurança, "ainda que em uma democracia, alguns setores da população têm que desaparecer pelo bem estar social" (TAYLOR, 2018, p. 322). Diana Taylor insiste em destacar as semelhanças entre planejadores urbanos e as forças militares da América Latina, que sabem, há muito tempo, que o extermínio pode "mudar o sentido e a memória que a sociedade tem de si mesma" (TAYLOR, 2018, p. 322). A cidade é um campo de batalha.

Uma década depois, em 2016, o El Reina Sofia, dos mais importantes museus do mundo - seja lá o que isso quer dizer, e qual mundo é esse - , localizado em Madrid, propôs-se a mostrar "el arte más político de su colección" (GARCíA, 2016). Deu no jornal! Seja como for, a obra do Mapa Teatro, desenvolvida especificamente para a mostra, era uma variação de Testigo de las ruínas. Já passou da hora em que posso admitir que adoro variações, apropriações, citações, roubos - Mapa Teatro roubando Heiner Müller me conquistou - talvez não tanto quanto sua grande deglutição de Samuel Beckett, nos primórdios de sua existência.

Estreia do Mapa Teatro na América Latina, De mortibus: réquiem para Samuel Beckett (1990) já anunciava a preferência dos Abderhalden por processos que operam dentro de uma lógica que evita a representação de narrações. O grupo trabalhou em cima de diversos textos do autor, articulando-

LAURENTIIS, Clara Barzaghi; PELBART, Peter Pal. Testemunhos da violência na obra do Mapa Teatro, Colômbia.

PÓS:Revista do Programa de Pós-graduação em Artes da EBA/UFMG. v.10, n.19: mai.2020 Disponível em < $\underline{\text { https://eba.ufmg.br/revistapos }>}$

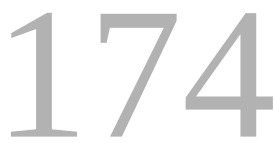


os a imagens e aos sons, numa mistura entre o material preexistente e aquilo que o próprio processo se encarrega de inventar. No espaço quadrado, influenciado por Quad, quatro personagens habitam um mundo cinza e calado, no qual a língua míngua e dá espaço aos movimentos curtos e suas composições lineares.

Se, ao longo dos anos, o grupo encheu de cores suas apresentações - afinal estamos no território da cumbia e do vallenato -, seus processos seguiram influenciados por Beckett (ABDERHALDEN, 2014). Os personagens que surgiram, e seguem ressurgindo, em suas produções, não se vinculam facilmente às identidades, não apenas porque as perderam, mas porque estão sempre em vias de se tornarem outrem.

Quando colocam em cena uma a última moradora de um bairro que deixou de existir, os Abderhalden conseguem escapar de uma possível espetacularização da miséria, pois a personagem que surge em Juana é composta de todos os relatos que aparecem ao longo da apresentação. No entanto, Juana não representa El Cartucho, tampouco um povo desterritorializado. Ela existe em seu ato e na reverberação desse ato, que a partir de um ponto não será mais dela e pode ele mesmo se tornar personagem.

Testigos de las ruínas é, então, o nome da instalação derivada da performance homônima, e consiste em uma videoinstalação composta por telas semelhantes às do cenário da performance original, também da máquina de fazer arepas. $\mathrm{O}$ material projetado nas telas remete à performance, mas Juana não está presente. O que chama a atenção é como a máquina traz, em si, toda uma rede de relações que envolve um circuito mulher-máquina-comida, que já não se refere à Juana que víamos em cena. A máquina, que chega a desaparecer quando olhamos a partir de certos ângulos, se compõe com as imagens dos telões. Se torna um monumento, que não celebra um passado, "é um bloco de sensações presentes que só devem a si mesmas sua própria conservação e dão ao acontecimento o composto que o celebra" (DELEUZE; GUATTARI, 2011, p. 218).

LAURENTIIS, Clara Barzaghi; PELBART, Peter Pal. Testemunhos da violência na obra do Mapa Teatro, Colômbia.

PÓS:Revista do Programa de Pós-graduação em Artes da EBA/UFMG. v.10, n.19: mai.2020 Disponível em < $\underline{\text { https://eba.ufmg.br/revistapos }}>$

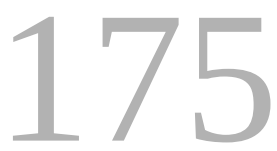




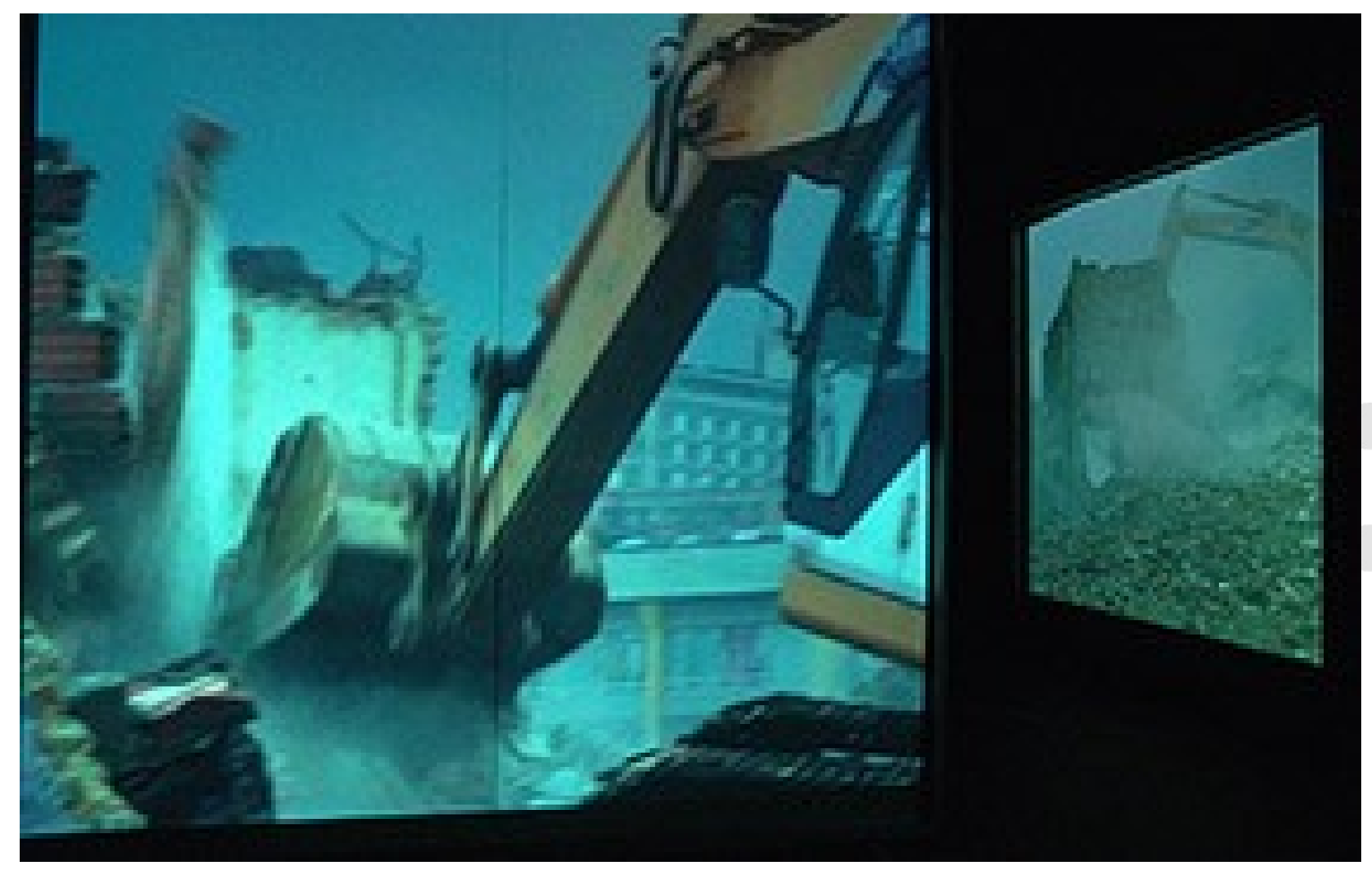

Fig. 3 - Mapa Teatro, Testigo de las Ruínas (variação), 2016 - Instalação, projeção em vídeo, cadeiras, máquina de fazer arepas, Museu Nacional Reina Sofia.

Se a oralidade é a via de acesso mais direta ao que o grupo chamou de arquivo vivo, o que permite que o registro não se resume ao documento histórico é a relação que se estabelece entre a disposição dos telões no espaço e a máquina de fazer arepas. Pois essa relação sustenta a carga poética e política da obra, conforme dá a ver territórios existenciais que se espalham para além dos mapas oficiais. Em meio a imagens documentais, a máquina de arepas ficciona os mundos que se construíram após a destruição do bairro, etnoficção que traz, ao presente, a existência de pessoas que tendem a ser esquecidas, lançadas para fora do centro e para longe dos imaginários.

As variações ${ }^{1}$ se tornaram experimentos recorrentes na produção do grupo e no mesmo Reina Sofia, atualmente, encontra-se uma variação da peça Los incontados: un tríptico (2012) 2. Nesta instalação, homônima à peça, "a caixa mágica da primeira cena adquiria protagonismo e o movimento das coisas já não requeria a colaboração do corpo vivo dos atores" (SÁNCHEZ, 2016, p. 319). O espectador pode adentrar aquela sala, com ares de aquário e com cheiro de ocre, pela qual se espa-

LAURENTIIS, Clara Barzaghi; PELBART, Peter Pal. Testemunhos da violência na obra do Mapa Teatro, Colômbia.

PÓS:Revista do Programa de Pós-graduação em Artes da EBA/UFMG. v.10, n.19: mai.2020 Disponível em < https://eba.ufmg.br/revistapos $>$

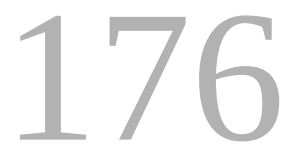


Iham a mata de coca e também vestígios de uma festa que não vimos acontecer de fato. O cenário se torna território pelo qual o público pode transitar enquanto vê um televisor com cenas de peças que compõem a anatomia da violência feita pelo Mapa Teatro.

As instalações propostas a partir de Los incontados e de Testigo de las ruínas são autônomas em relação a qualquer drama, ou seja, não dependem da atuação decidida das pessoas. Os vestígios da festa interrompida de Los incontados se tornam uma espécie de arquivo sobre a violência, arquivo que não imita a História. É preciso ser daqui para sentir certo prazer com a dor, o espectador descobre ao adentrar a sala onde outrora (na peça) crianças marchavam enquanto na rádio ressoava o discurso de Camilo Torres. Da América do Sul, do Sol, do sal do sangue de negros escravizados, que hoje correm livres pelas ruas de Guapi, açoitando-se quando chega a festa dos Santos Inocentes.

Pois, se a máquina de Juana se torna uma espécie de monumento do arquivo de El Cartucho, o ponto de partida de uma das variações de Los Santos Inocentes ${ }^{3}$ (peça 2010, instalação 2015) não é um objeto, mas um gesto. Ao revisitar a festa de Guapi, o grupo inventou um mecanismo com um chicote acoplado que, ao se movimentar, açoita uma parede. O movimento não varia de ritmo e, a cada golpe, o lado oposto da parede é iluminado com imagens da festa dos Santos Inocentes e a sala se enche com o som da chicotada.

A violência que se espalhava pelas ruas da festa agora pertence a uma única máquina. A festa resta apenas como conjunto de imagens que se projetam quase como fantasmas, ao som do chicote, que soa como um discurso de poder. Nos trabalhos do Mapa Teatro sempre parecem estar em jogo as formas como as codificações do poder operam, física e subjetivamente, entre os corpos individuais, coletivos e sociais. Existe um discurso que legitima o uso da violência pelo aparelho de Estado, e suas extensões, e a renomeia justiça (LAPOUJADE, 2015). Define-se, assim, o que será ou não considerado violento - será sempre o que vem de fora, o bárbaro, o outro. A dimensão festiva que há no carnaval violento de Guapi é vinculada a comportamentos selvagens ou bárbaros, um espetáculo de violência que deve ser confiscado. Uma única máquina deterá o monopólio legítimo da violência. E seguirá chicoteando sob o signo da justiça.

LAURENTIIS, Clara Barzaghi; PELBART, Peter Pal. Testemunhos da violência na obra do Mapa Teatro, Colômbia.

PÓS:Revista do Programa de Pós-graduação em Artes da EBA/UFMG. v.10, n.19: mai.2020 Disponível em < https://eba.ufmg.br/revistapos $>$

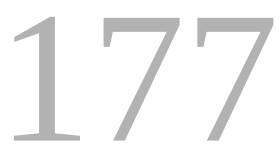




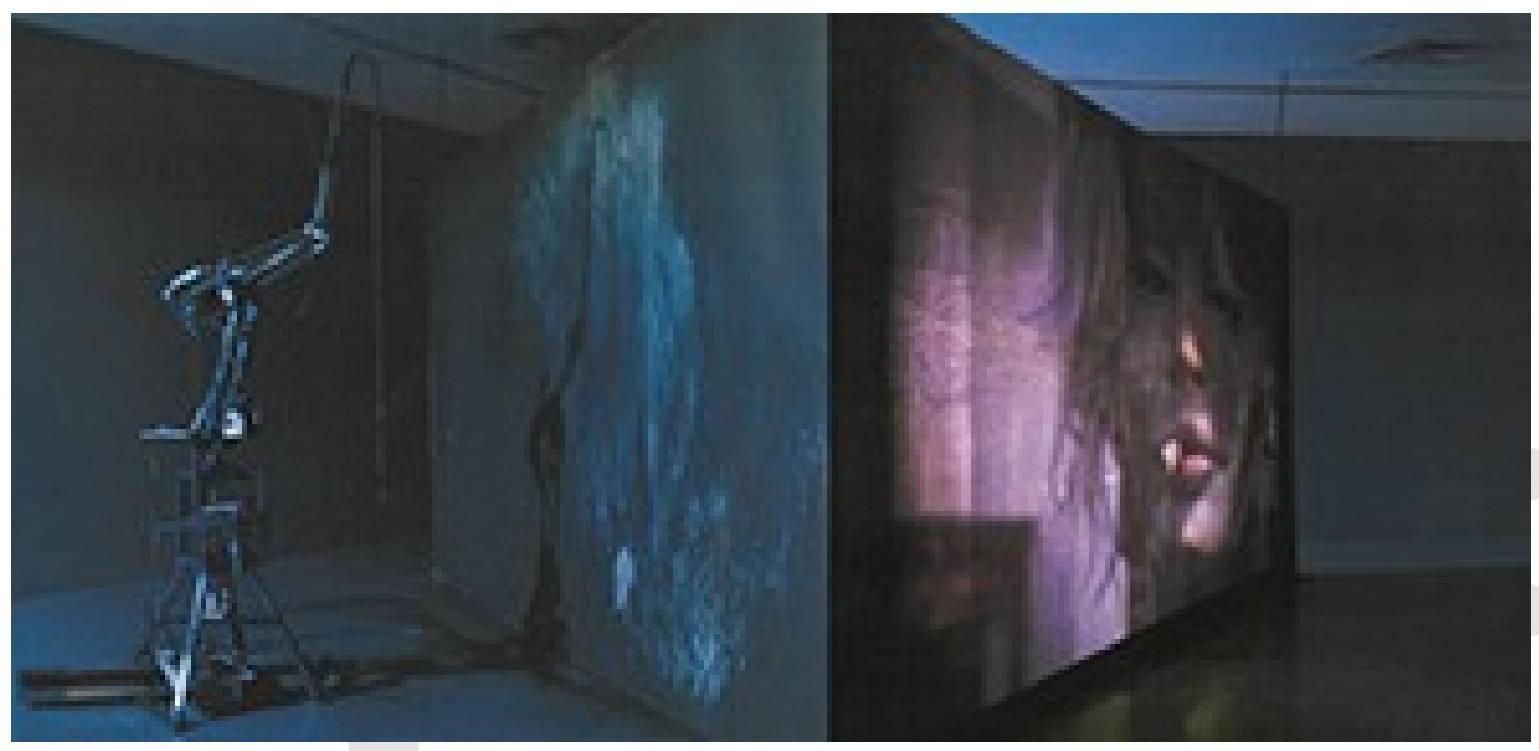

Fig. 4 - Mapa Teatro, Los santos inocentes (variação), 2015, Instalação, parede de madeira e grafite, projeção em vídeo, máquina. Encuentro Internacional de Arte de Medellín MD15, Medelín, Colômbia.

De um lado da instalação temos a máquina, que captura a violência e a festa, e chicoteia sistematicamente a parede. Do outro, as breves projeções mostram algo de incapturável, lembrança constante de que no ano seguinte as ruas de Guapi estarão cheias de homens mascarados, com seus chicotes na mão, na festa e na fúria. Fúria que se converte em protesto no final das peças Los Santos Inocentes e Los incontados, quando as ruas de Guapi cantam pela saída de paramilitares e guerriIheiros de seu território. Fúria posta em cena também em uma das variações de Los Santos inocentes (2011), bem como na própria peça, quando um homem mascarado golpeia o nada por mais tempo do que é confortável para o público. Aqui, é o próprio gesto em sua repetição que traz a carga poética e política da obra, por trazer a força de um esquecimento contido na revolta que está além da História.

Com suas variações, o Mapa Teatro revisita seus trabalhos e constrói o que chama de arquivo vivo. Esse conceito é encontrado pelo grupo nas proposições de Suely Rolnik (ROLNIK, 2012) sobre as possibilidades de trabalhar com imagens e objetos para além da documentação. São formas de atualizar as inquietações encontradas ao longo dos trabalhos, revisitando-as e produzindo "memórias vivas" (ROLNIK, 2007). Em suas instalações, o grupo transpõe suas peças para museus sem, no entanto, restringir-se à documentação de arte. Os Abderhalden conseguem construir monu-

LAURENTIIS, Clara Barzaghi; PELBART, Peter Pal. Testemunhos da violência na obra do Mapa Teatro, Colômbia.

PÓS:Revista do Programa de Pós-graduação em Artes da EBA/UFMG. v.10, n.19: mai.2020

Disponível em < $\underline{\text { https://eba.ufmg.br/revistapos }>}$

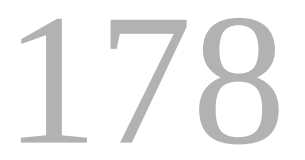


mentos, como a máquina de arepas, que são compostos de sensações. Cada qual a sua maneira se reconfigura, transforma-se e se cria na relação com o público. Expandindo o campo do teatro, o grupo encontra linguagens para situações ou sítios específicos, e opera de forma que o "vivo" não dependa, necessariamente, da presença dos atores.

Mas a noção de arquivo vivo não se restringe às variações pensadas para museus. Já na experiência com Beckett é notável a opção dos Abderhalden em evitar representações tradicionais, preferindo trazer à cena os resultados de sua deglutição do autor. E, antes de ser transformada em instalação, Testigo de las ruínas foi uma tentativa de colocar em cena, por meio da articulação entre registro documental e a presença de Juana, um arquivo vivo, em constante construção.

Na peça, o arquivo apresentado não se resume a registro de um passado, pois à medida que se apresentam os relatos que não sabemos mais se são de dona Elisa, de Ernesto Carlos, de dona Guillermina, ou de quaisquer outrem que talvez não constem sequer nos registros do Mapa Teatro, o que se ouve nem sempre corresponde ao que se vê projetado nas cinco grandes telas em cena.

O que se vê nas imagens é também o presente, o dia a dia do bairro que agora já foi o parque do futuro e nos dias de hoje voltou a estar rodeado dos ditos indesejados. Eventualmente, corpos que são telas em que se projeta o presente estão em cena e não podem nada além de ser testemunhas dos relatos dos outros. É o que cabe aos integrantes do grupo, que entendem que unir seu corpo ao mundo de outrem não é sobrepô-lo. Projetores e telas se movem e seus corpos são extensões dessas telas, que se manifestam na paisagem como testemunhas.

O Mapa Teatro trabalha o material coletado combinando imagens de El Cartucho e seus antigos moradores com as palavras trazidas por essas testemunhas. Nesse processo, não vemos imagens do que costumava ser o bairro sobre o qual falam aquelas pessoas, pois as projeções mostram apenas o presente de sua demolição. À medida que falam, os moradores constroem suas memórias daquele território e na montagem e na encenação o Mapa Teatro apresenta um presente que "coexiste com um passado e com um futuro sem os quais ele não passaria" (DELEUZE, 2013, p. 52).

LAURENTIIS, Clara Barzaghi; PELBART, Peter Pal. Testemunhos da violência na obra do Mapa Teatro, Colômbia.

PÓS:Revista do Programa de Pós-graduação em Artes da EBA/UFMG. v.10, n.19: mai.2020 Disponível em < $\underline{\text { https://eba.ufmg.br/revistapos }>}$

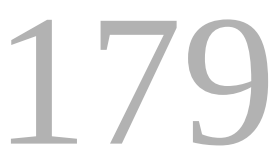


A peça apresenta testemunhos de um passado sem, no entanto, mostrá-lo. Diante das imagens da demolição, que se alternam com registros dos moradores, o espectador se vê forçado a criar suas próprias memórias do bairro. O público é jogado em uma posição de agente, conforme os relatos fazem com que cada um da plateia se torne testemunha da desapropriação, destruição e "revitalização" de El Cartucho. Porém, os espectadores se deparam com a impossibilidade de serem testemunhas verdadeiras, por não terem vivido as memórias que criam enquanto assistem a Testigo de las ruínas. O que testemunham, afinal?

Conforme o público se torna responsável por construir sua própria memória, não ocupa uma posição imparcial de apreensão do que vê. Os espectadores se tornam agentes cujas percepções deixam de ser neutras e podem suscitar "o desejo de testemunhar 'a favor' da importância ou da beleza do que elas viram" (LAPOUJADE, 2017, p. 22).

A presença do público intensifica os territórios existenciais que aparecem conforme a memória do bairro se constrói. Memória inventada pelas articulações entre os relatos e documentações e os espectadores. O público pode, então, tornar-se testemunha que tem "a responsabilidade de fazer ver aquilo que teve o privilégio de ver, sentir ou pensar" (LAPOUJADE, 2017, p. 22). Tal operação situa o Mapa Teatro na posição de uma espécie de advogado, que convoca suas testemunhas, ou seja, o grupo cria situações poéticas que possibilitam um agenciamento com os espectadores e, nessa articulação, advogados e testemunhas "fazem existir novas entidades, produzem novas realidades em que antes ninguém tinha visto nada" (LAPOUJADE, 2017, p. 23).

No entanto, para além dos registros de relatos orais ou das imagens documentais do processo de destruição do bairro, é a presença de Juana em frente às telas, manejando sua máquina e fazendo arepas, sobre uma mesa no centro do palco, que cava uma carga poética - por vezes incômoda capaz de tornar a plateia parte do testemunho.

LAURENTIIS, Clara Barzaghi; PELBART, Peter Pal. Testemunhos da violência na obra do Mapa Teatro, Colômbia.

PÓS:Revista do Programa de Pós-graduação em Artes da EBA/UFMG. v.10, n.19: mai.2020 Disponível em < $\underline{\text { https://eba.ufmg.br/revistapos }}>$ 


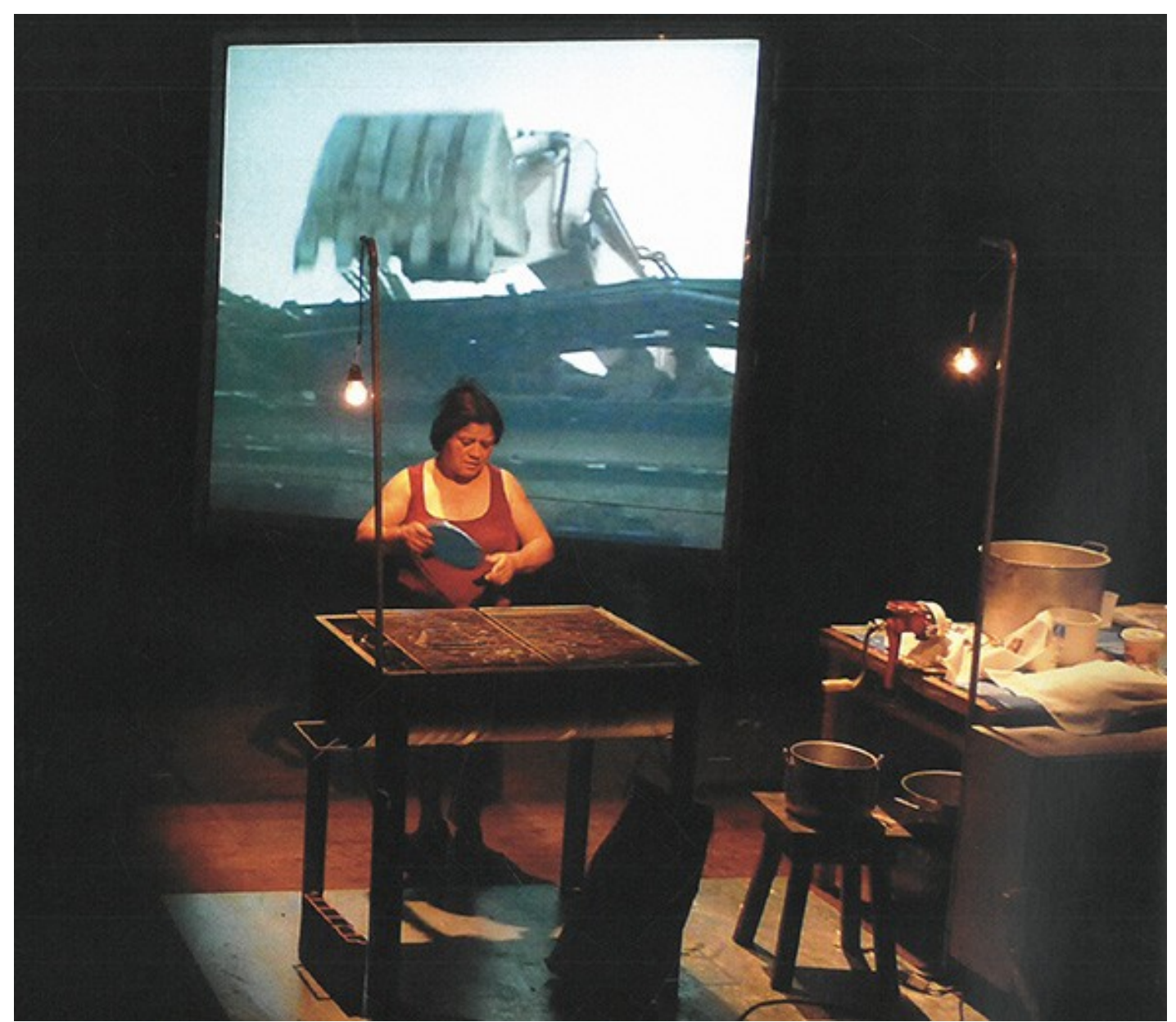

Fig. 5 - Mapa Teatro, Testigo de las Ruínas, 2005. Bogotá, Colômbia.

A presença de Juana não representa nada. Sua presença viva traz consigo algo de seu território existencial que não se resume ao espaço que já não existe. Ao longo de toda a peça, a manivela da máquina segue, bem como a presença viva da última moradora do bairro demolido.

Juana não é uma imagem, mas uma vida. Não faz parte do que se pode chamar de arquivo, seja ele vivo ou morto. Está em cena como convidada, não tanto testemunha, tampouco vítima. Sua presença é a vida que, colocada em cena, agencia afetos e pode convocar sensações no espectador, que passa a ser testemunha da demolição do bairro e da destruição dos territórios de todos que contam suas memórias.

LAURENTIIS, Clara Barzaghi; PELBART, Peter Pal. Testemunhos da violência na obra do Mapa Teatro, Colômbia.

PÓS:Revista do Programa de Pós-graduação em Artes da EBA/UFMG. v.10, n.19: mai.2020 Disponível em < https://eba.ufmg.br/revistapos $>$

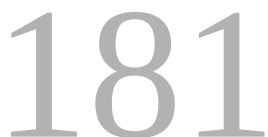




\section{REFERÊNCIAS}

ABDERHALDEN, Rolf. Mapa Mundi: Plurivers Poïétique - Mapa Teatro (1984-2014). Tese de doutorado. Université Partis VIII - Saint Denis, 2014, p. 153-161.

DELEUZE, Gilles. A imagem-tempo. São Paulo: Editora Brasiliense, 2013.

DELEUZE, Gilles. Conversações. São Paulo, SP. Editora 34, 2008.

DELEUZE, Gilles; GUATTARI. Felix. O que é a filosofia? São Paulo: Editora 34, 2011.

GARCÍA, Ángeles. El Reina Sofía muestra el arte más político de su colección. El país. Espanha, 28 oct. 2016. Disponível em:

https://elpais.com/cultura/2016/10/25/actualidad/1477406910_314037.html. Acesso em: 5 maio 2020.

GUATTARI, Félix. Espaço e poder: a criação de territórios na cidade. Revista estudos regionais e urbanos, São Paulo, ano 5, n.16, p. 1985.

LAPOUJADE, David. As existências mínimas. São Paulo: n-1 edições, 2017.

LAPOUJADE, David. Fundar a violência: uma mitologia? In: NOVAES, Adauto (Org.). Mutações: fontes passionais da violência. São Paulo: Sesc, 2015, 2015. p. 79-94.

ROLNIK, Suely. Furor de arquivo. Arte e Ensaios, Rio de Janeiro, n.19. p. 97-105, 2012.

ROLNIK, Suely. The Body's Contagious Memory: Lygia Clark's Return to the Museum. eipcp. 2007. Disponível em: http://eipcp.net/transversal/0507/rolnik/en. Acesso em: 5 maio 2020.

SÁNCHEZ, José A. Ética y representación. Cidade do México: Paso de Gato, 2016.

SÁNCHEZ, José A. Prácticas de lo real en la escena contemporânea. Madri: Visor Libros. 2007.

TAYLOR, Diana. Testigo de las ruínas. In: RODRIGUEZ, Marta (ed.) Mapa Teatro: El escenario expandido. Bogotá: Editorial Universidad Nacional de Colombia, 2018. p. 317-330.

LAURENTIIS, Clara Barzaghi; PELBART, Peter Pal. Testemunhos da violência na obra do Mapa Teatro, Colômbia.

PÓS:Revista do Programa de Pós-graduação em Artes da EBA/UFMG. v.10, n.19: mai.2020

Disponível em < $\underline{\text { https://eba.ufmg.br/revistapos }}>$

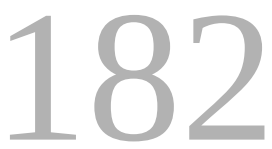




\section{NOTAS}

1 Agradeço à Ximena Vargas pela conversa realizada em novembro de 2016, quando me mostrou alguns registros das variações do Mapa Teatro, que à época eu mal conhecia.

2 Los incontados: un tríptico, foi a terceira na cronologia das quatro peças que compõem o tríptico em torno da Violência proposto pelo laboratório de artistas Mapa Teatro.

3 Em Los Santos Inocentes, primeira peça da Anatomia de Violência na Colômbia, o grupo aborda a violência dos grupos paramilitares a partir de um dispositivo cênico elaborado em torno da festa dos Santos Inocentes, que acontece todo dia 28 de Dezembro em Guapi, um povoado ilhado na costa pacífica colombiana. 